\title{
Comparative evaluation of odorous compound absorption between goat milk and cow milk
}

\author{
Yoshiaki Hayashi* and Natsuki Ueno
}

Laboratory of Plant and Animal Science (Livestock Production), Experimental Farm, Faculty of Agriculture, Meijo University, 4311-2, Hishigaike, Takaki-cho, Kasugai 486-0804, Japan.

Accepted 20 December, 2017

\begin{abstract}
Milk is presumed to readily absorb surrounding odorous compounds. However, the difference of odorous substance absorption between goat milk and cow milk is still obscure. Thus, this study was conducted for comparative evaluation of odorous compound absorption of goat and cow milk. A milk sample in an opened plastic box and fresh chicken droppings in an opened plastic bag were gathered into a sealed box as treatment groups (TG: goat, TC: cow). Control groups without chicken droppings were also settled (CG: goat, CC: cow) with the same method as treatment groups. All the groups were incubated at $20^{\circ} \mathrm{C}$ for $24 \mathrm{~h}$. Methyl mercaptan (MM), dimethyl sulfide (DMS) and ammonia $\left(\mathrm{NH}_{3}\right)$ concentrations as odorous compounds were derived from the milk samples before and after the incubation. The concentration of MM in TC was higher than that in TG, CG and CC at the post-incubation $(P<0.01)$. The concentration of DMS was higher in TG and TC than in CG and CC (P<0.01). The absorption of DMS between TG and TC was in comparable level after the incubation. On the other hand, the concentration of $\mathrm{NH}_{3}$ was not significantly different in the milk before and after the incubation. The $\mathrm{NH}_{3}$ might have not been absorbed by the milk and have been volatilized from the milk. These results showed that the absorption of MM was lower in goat milk than in cow milk, and indicated that goat milk might have possibilities to absorb some of the odorous compounds less than cow milk.
\end{abstract}

Keywords: Absorption, cow, goat, milk, odor.

*Corresponding author. E-mail: yoshiha@meijo-u.ac.jp. Tel: +81-568-41-8838. Fax: +81-568-81-1589.

\section{INTRODUCTION}

Contributions of goat production to agricultural economy are considerable in many countries now. According to FAOSTAT (2017), the goat population in the world increased by around 58\% between 1994 and 2014, while the population of cattle grew by about $13 \%$. Milk production of goats in the world increased by around 59\% between 1994 and 2014 (FAOSTAT, 2017). These growths in goat production indicated high potential for further improvements. The goat milk is suitable as potential substitute for cow milk products in the diets of people with cow milk allergies due to low concentration of $\alpha_{\mathrm{S} 1}$-casein (Clark and Sherbon, 2000), which is the main allergen in milk (Docena et al., 1996). Goat milk possesses the other advantages over cow milk, for use as a nutritional source for infants and children, and as a medicinal food due to the composition and digestibility of milk. Although the casein micelles in goat milk are bigger than those in cow milk, the size of fat globules is smaller (Silanikove et al., 2010). In addition, goat milk is reported to have form a fine curd compared to cow milk, suggesting it would be more easily digested. Therefore, goat milk is receiving interests of many consumers in view of its higher tolerability and digestibility. However, a possible problem of "goaty" flavor in goat milk and products due to higher proportion of short or mediumchain fatty acids, that is, caproic (C6:0), caprylic (C8:0) and capric (C10:0), is present. This flavor is influenced by factors such as goat breed, feeding trait and industrial process (Skjevdal, 1979; Morgan and Gaborit, 2001; Chilliard et al., 2003). On the other hand, goat milk was assumed to absorb the circumstance odors easily in some area, that is, livestock farm and milk processing area. Milk was reported to show a high deodorizing activity against many sulfide and disulfide volatiles. For 
example, cow milk captured the volatiles arise from Allium plants around $90 \%$ (Negishi et al., 2002). This reaction shows that milk can absorb volatile odorous compounds. However, milk has not been investigated for its capability to absorb the malodorous compounds from materials in livestock production.

Malodorous compounds are present in livestock farming, though reductions of the compounds in the farming are required for an appropriate environment. Malodorous substances can be divided into some different chemical classes (Rappert and Muller, 2005). Volatile sulfur compounds include methyl mercaptan (MM) and dimethyl sulfide (DMS). These compounds are produced by anaerobic microbial degradation of sulfurcontaining amino acids such as methionine and cysteine (Aldin et al., 2011), and have been known as a major substances causing off-flavor from livestock feces. On the other hand, ammonia $\left(\mathrm{NH}_{3}\right)$ possibly becomes the main volatile odorous compound from livestock farming area. Approximately $40 \%$ of anthropogenic $\mathrm{NH}_{3}$ emissions are associated with manures from livestock production (Galloway et al., 2004). This substance is caused by decomposition of urine, uric acid and nitrogenous compounds like proteins and amino acids.

These odorous substances might be absorbed by milk during milking or handling in livestock farms. Milk from various dairy animals may have different characteristics for absorption of odorous compounds. However, a literature review found no published information on the odorous substance absorption in milk of different animals. Hence, the objective of the study was to evaluate the odorous compound absorption using a malodorous material between goat milk and cow milk for obtaining the first fundamental information.

\section{MATERIALS AND METHODS}

\section{Materials}

Goat milk was collected from a Japanese Saanen doe (64 months of age and third parity) raised in Experimental farm, Faculty of Agriculture, Meijo University, Kasugai, Japan. The goat was fed 2.0 $\mathrm{kg}$ of fescue straw, $0.9 \mathrm{~kg}$ of barley and $0.9 \mathrm{~kg}$ of wheat bran per day. Cow milk was taken from a bulk tank of 21 Holstein cows (61.2 month of age and 2.8th parity on an average) raised at Ito dairy farm in Shinshiro, Japan. The cows were fed rye grass silage ad libitum, $2.0 \mathrm{~kg}$ of beet pulp and $8.0 \mathrm{~kg}$ of concentrate feeds per day per cow on an average. Each milk sample was frozen just after the collection and kept at $-28^{\circ} \mathrm{C}$ until the time of analyses and experiments. Fresh chicken droppings as a malodorous material were collected from 20 White Leghorn hens reared in Experimental farm, Faculty of Agriculture, Meijo University, Kasugai, Japan at the same day of the experiment. The hens were fed commercial layer feed ad libitum.

\section{Analysis of milk characteristics}

The milk samples were determined for $\mathrm{pH}$, specific gravity and milk constituents such as total solids, fat, protein and ash. The $\mathrm{pH}$ was determined by a $\mathrm{pH}$ meter and the specific gravity was measured by a lactometer (Sansyo Co., Ltd., Tokyo, Japan) calibrated at $15.6^{\circ} \mathrm{C}$. A correction to be applied to a lactometer readings for the other temperatures was followed by the correction table as suggested by Prasad et al. (1999). The concentration of total solids in a $10 \mathrm{ml}$ milk sample was obtained by drying in an oven (Advantec Toyo Co., Ltd., Tokyo, Japan) at $105^{\circ} \mathrm{C}$ until constant weight was reached. The fat content was analyzed using a Gerber butyrometer (Shibata Scientific Technology Ltd., Soka, Japan); protein was determined through the Kjeldahl method, multiplying 6.38 by the nitrogen percentage (AOAC, 1990). The analysis of ash percentage was measured by a muffle furnace (Advantec Toyo Co., Ltd., Tokyo, Japan) at $600^{\circ} \mathrm{C}$ for $3 \mathrm{~h}$. The solid-not-fat (SNF) content was determined by subtracting the concentration of fat from total solids. The content of the other solids were calculated by subtracting the concentrations of protein and ash from SNF.

\section{Analysis of odorous compounds derived from milk}

After the frozen milk samples were melt in a water bath at $38^{\circ} \mathrm{C}$, the milk sample $(550 \mathrm{ml})$ in an opened plastic box and fresh chicken droppings ( $450 \mathrm{~g}$ of fresh matter) in an opened plastic bag were gathered into a sealed box $(276 \mathrm{~mm} \times 204 \mathrm{~mm} \times 101 \mathrm{~mm})$ as treatment groups (TG: goat, TC: cow). The milk sample $(550 \mathrm{ml})$ in an opened plastic box without fresh chicken droppings in the same size of sealed box of the treatment groups also settled as control groups (CG: goat, CC: cow). All the sealed boxes were incubated at $20^{\circ} \mathrm{C}$ for $24 \mathrm{~h}$. The milk in each box was transferred to sealed bottles after an incubation. The half amount of milk was placed at $35^{\circ} \mathrm{C}$ for $5 \mathrm{~h}$ for gas collection from milk. Gas derived from the milk was collected with an air-tight syringe and applied into a gas chromatograph for analyzing MM and DMS concentrations. The gas chromatograph used was a GC-2014 (Shimadzu Co., Ltd., Kyoto, Japan), interfaced to a flame photometric detector (FPD). Separation of MM and DMS was done by a packed column ( $\beta, \beta$ 'ODPN $25 \%$ on Chromosorb W (AW. DMCS) (60/80 mesh), Glass 3 $\mathrm{m}$ length $\times 3 \mathrm{~mm}$ i.d.; $25.0 \mu \mathrm{m}$ film thickness). The conditions were the following: carrier gas flow rate, $60 \mathrm{ml} / \mathrm{min}$.; injector temperature, $150^{\circ} \mathrm{C}$; detector temperature, $150^{\circ} \mathrm{C}$ and column temperature, $70^{\circ} \mathrm{C}$. Identification of MM and DMS was conducted by the retention time with reference to MM and DMS standard solutions. The $\mathrm{NH}_{3}$, as an effluent gas from the other half amount of milk with the incubation at $35^{\circ} \mathrm{C}$ for $35 \mathrm{~min}$, was collected into $0.5 \%$ boric acid solution using a vacuum pump. The $10 \mathrm{ml}$ of boric acid solution was mixed with $5 \mathrm{ml}$ of phenol-sodium nitroprusside and $5 \mathrm{ml}$ of sodium hydrochloride. The concentration of $\mathrm{NH}_{3}$ was determined by colorimetric method using $640 \mathrm{~nm}$ with UV/VIS spectrophotometer V-530 (Jasco Co., Hachioji, Japan).

\section{Statistical analysis}

The experiments were conducted with 8 replicates. The differences in mean values of odorous substances and milk quality according to the treatments were analyzed by Tukey's multiple comparison test. All calculations were made using a commercially available computer program (Excel Statistics; SSRI Co., Ltd., Tokyo, Japan).

\section{RESULTS}

\section{Milk characteristics}

Characteristics of goat milk and cow milk collected in this study are shown in Table 1. The values of specific gravity 
Table 1. Characteristics of goat milk and cow milk.

\begin{tabular}{lcc}
\hline Parameter & Goat & Cow \\
\hline pH & 6.49 & 6.52 \\
Specific gravity & 1.0286 & 1.0301 \\
Total solids (\%) & 10.95 & 11.23 \\
Solid-not-fat (\%) & 7.80 & 8.01 \\
Ash (\%) & 0.79 & 0.74 \\
Fat (\%) & 3.15 & 3.23 \\
Protein (\%) & 2.95 & 2.94 \\
Other solids (\%) & 4.07 & 4.33 \\
\hline
\end{tabular}

and total solids of the cow milk tended to be higher than those of the goat milk. However, all the milk characteristics between the goat milk and the cow milk had no significant difference.

\section{Odorous compounds derived from milk}

Concentration of odorous compounds from the goat milk and the cow milk before and after the incubation is shown in Table 2. Although MM was not detected before the experiment, DMS and $\mathrm{NH}_{3}$ were found prior to the incubation. The DMS concentration was tended to be higher in the cow milk than in the goat milk prior to the incubation. On the other hand, no significant difference was shown in $\mathrm{NH}_{3}$ concentration between the goat milk and the cow milk.

The MM concentration in TC was significantly $(\mathrm{P}<$ $0.01)$ higher than that in TG, CG and CC. However, the concentration of DMS was significantly $(P<0.01)$ higher in $T G$ and TC than in $C G$ and $C C$. In addition, the DMS concentration in TG and TC was significantly $(P<0.01)$ higher than the milk before the incubation in both the goat milk and the cow milk. The mean of DMS concentration showed no significant difference from the milk between the prior to incubation and the post incubation without the droppings in both the animals. The content of $\mathrm{NH}_{3}$ from milk after the incubation did not show significant difference among the groups. The mean of $\mathrm{NH}_{3}$ concentration also showed no significant difference between the milk before and after the incubation in both animals.

Table 2. Concentration of odorous compounds from goat milk and cow milk.

\begin{tabular}{|c|c|c|c|c|c|c|c|}
\hline \multirow{2}{*}{ Parameter } & \multicolumn{2}{|c|}{ Before incubation } & \multicolumn{4}{|c|}{ After incubation } & \multirow{2}{*}{ SEM } \\
\hline & Goat & Cow & TG & $\mathbf{C G}$ & TC & CC & \\
\hline $\mathrm{MM}(\mathrm{ng} / \mathrm{ml})$ & $0^{b}$ & $0^{\mathrm{b}}$ & $1.50^{b}$ & $0.12^{b}$ & $4.95^{\mathrm{a}}$ & $0.40^{\mathrm{b}}$ & 0.40 \\
\hline DMS (ng/ml) & $0.08^{b}$ & $0.49^{b}$ & $58.00^{a}$ & $1.32^{b}$ & $58.70^{\mathrm{a}}$ & $4.69^{b}$ & 4.94 \\
\hline Ammonia (ng/ml) & 11.40 & 13.76 & 9.48 & 10.51 & 8.00 & 10.49 & 1.13 \\
\hline
\end{tabular}

\section{DISCUSSION}

It is suggested that the DMS contributed to the characteristic flavor of raw milk even at low concentrations (Patton et al., 1956). In addition, DMS can be transferred easily from rumen to milk (Shipe et al., 1962). The precursor of DMS was identified as S-methyl methionine sulfonium salts (MMS) in milk (Keenan and Lindsay, 1968). Thus, this odorous substance was detected from both the goat milk and the cow milk even before the incubation. Dunham et al. (1968) reported that cows fed alfalfa hay plus $26 \mathrm{~g}$ of $90 \%$ DL-methionine yielded more methyl sulfide in milk than those fed alfalfa hay alone. The MMS is widespread in plant materials (Keenan and Lindsay, 1968). Thus, the different feed materials between the goat and the cows in this study might have affected the variance of DMS concentration from the milk. In addition, cow milk possibly have higher MMS contents than goat milk, though the analysis of MMS concentration in milk was not conducted in this study. Thus, these possibilities might have caused the higher tendency of DMS concentration in the cow milk before the incubation. On the other hand, mammals have urea as the main form of excretory nitrogen in milk. This urea derives from the detoxifying conversion in the liver of $\mathrm{NH}_{3}$ circulating in the blood. Protein and urea nitrogen in milk have possibilities to be hydrolyzed to $\mathrm{NH}_{3}$ by urease enzyme. Consequently, this odorous compound was also detected from both the animals' milk before the exposure to chicken droppings, though the concentration of urea nitrogen in milk was not analyzed in this study. The $\mathrm{NH}_{3}$ emission from milk might have been comparable in both the animals' milk. The $\mathrm{NH}_{3}$ was identified to be the major volatile compound before the incubation among the three odorous substances in this study.

The MM detected from TC can be considered as substances absorbed by milk from the droppings during the incubation at $20^{\circ} \mathrm{C}$ for $24 \mathrm{~h}$. Negishi et al. (2002) reported that cow milk effectively captured diallyl disulfide and diallyl sulfide by physical and chemical interactions 
between the volatile sulfur compounds and milk components such as protein or lipid. This reaction indicated that milk absorbed the volatile sulfur compounds. In addition, sodium caseinate was reported to interact with diallyl disulfide and allyl methyl disulfide via the sulfhydryl-disulfide interchange reaction (Jocelyn, 1972). Ceballos et al. (2009) reported that the amount of $a_{\mathrm{S} 1}$-casein was lower in goat milk than in cow milk, though total casein concentration between the different species was similar under the comparable feeding condition. Thus, the different composition of casein between goat milk and cow milk possibly have caused the difference of MM absorption.

The concentration of DMS in milk was higher with the droppings than without the droppings. In addition, the DMS content in CG and CC had no significant difference with the milk before the incubation in both the animals. The DMS can be considered to transfer from the droppings to milk in the treatment groups. However, the DMS appearance was comparable in TG and TC. Hansanugrum and Barringer (2010) reported that both oil and water in milk have a significant effect on the absorption of volatile compounds. Oil was reported to decrease the volatility of the more hydrophobic compounds better than water, whereas water was indicated to decrease the volatility of the more hydrophilic compounds better than oil. Since the concentrations of fat (oil) and water between the goat milk and the cow milk was comparable according to the results of milk characteristics in this study (Table 1), the similar amount of DMS might have been absorbed in both the animals' milk. Consequently, DMS was identified to be the most amount of volatile compound from the milk after the incubation with chicken droppings among the three odorous substances in this study.

Ammonia in milk was formed by protein and urea hydrolysis (Sherman et al., 1907; van Duinkerken et al., 2011). The microorganisms contained in milk possibly increased ammonia and proteolytic products. In addition, urea hydrolysis is catalyzed by urease, which is released by bacteria. Therefore, ammonia was detected from the milk even before incubation. Chicken droppings generally contain nitrogen, especially the uric acid. The uric acid was well degraded to $\mathrm{NH}_{3}$ by uricase. The mean of $\mathrm{NH}_{3}$ concentration also showed no significant difference between the milk before and after the incubation. In addition, the content of $\mathrm{NH}_{3}$ from milk after the incubation did not show significant difference among the groups. Therefore, the milk might not have absorbed $\mathrm{NH}_{3}$ during the experiment. Instead of the absorption, the milk possibly volatilized $\mathrm{NH}_{3}$ by itself. Thus, the $\mathrm{NH}_{3}$ was also the major odorous substances from the milk in this study.

\section{Conclusion}

Milk absorbed some of the surrounding odorous substances. The absorption of MM was lower in the goat milk than in the cow milk after the exposure to the chicken droppings at $20^{\circ} \mathrm{C}$ for $24 \mathrm{~h}$. On the other hand, the DMS was absorbed by both the animals' milk in the comparable level during the exposure to the droppings at $20^{\circ} \mathrm{C}$ for $24 \mathrm{~h}$. However, both the goat milk and cow milk were assumed not to absorb $\mathrm{NH}_{3}$ but to emit $\mathrm{NH}_{3}$ by itself. However, further investigations with the other odorous substances between goat milk and cow milk are necessary for evaluating odorous compound absorption of milk.

\section{REFERENCES}

Aldin S, Tu F, Nakhla G, Ray MB, 2011. Simulating the degradation of odor precursors in primary and waste-activated sludge during anaerobic digestion. Appl Biochem Biotech, 164: 1292-1304.

AOAC, 1990. Association of Official Analytical Chemists, Official Methods of Analysis. 15th Ed. AOAC, Arlington, VA.

Ceballos LS, Morales ER, Adarve GT, Castro JD, Martinez LP, Sampelayo MRS, 2009. Composition of goat and cow milk produced under similar conditions and analyzed by identical methodology. J Food Compos Anal, 22: 322-329.

Chilliard Y, Ferlay A, Rouel J, Lamberet G, 2003. A review of nutritional and physiological factors affecting goat milk lipid synthesis and lipolysis. J Dairy Sci, 86: 1751-1770.

Clark S, Sherbon JW, 2000. Alpha s1-casein, milk composition and coagulation properties of goat milk. Small Rumin Res, 38: 123-134.

Docena GH, Fernandez R, Chirdo FG, Fossati CA, 1996. Identification of casein as the major allergenic and antigenic protein of cow's milk. Allergy 51: 412-416.

Dunham JR, Ward G, Bassette R, Reddy, MC, 1968. Methionine as a precursor of methyl sulfide in cows' milk. J Dairy Sci, 51: 199-201.

FAOSTAT, 2017. Data, Food and Agriculture Organization of United Nations (FAO). http://www.fao.org/faostat/en/\#data (Accessed on November 9, 2017).

Galloway JN, Dentener FJ, Capone DG, Boyer EW, Howarth RW, Seitzinger SP, Asner GP, Cleveland CC, Green PA, Holland EA, Karl DM, Michaels AF, Porter JH, Townsend AR, Vorosmarty CJ, 2004. Nitrogen cycles: past, present, and future. Biogeochemistry, 70: 153226.

Hansanugrum A, Barringer SA, 2010. Effect of milk on the deodorization of malodorous breath after garlic ingestion. J Food Sci, 75: C549-C558.

Jocelyn PC, 1972. Biochemistry of SH group. Academic Press Inc, New York, pp. 404.

Keenan TW, Lindsay RC, 1968. Evidence for a dimethyl sulfide precursor in milk. J Dairy Sci, 51: 112-113.

Morgan N, Gaborit P, 2001. The typical flavor of goat milk products: technological aspects. Int J Dairy Technol, 54: 38-40.

Negishi O, Negishi Y, Ozawa T, 2002. Effects of food materials on removal of Allium-specific volatile sulfur compounds. J Agric Food Chem, 50: 3856-3861.

Patton S, Forss DA, Day EA, 1956. Methyl sulfide and the flavor of milk. J Dairy Sci, 39: 1469-1470.

Prasad J, Tyagi AK, Neeraj, 1999. Principles and practices of animal nutrition. Kalyani Publishers, Ludhiana, pp. 192.

Rappert S, Muller R, 2005. Odor compounds in waste gas emissions from agricultural operations and food industries. Waste Manage, 24: 887-907.

Sherman HC, Berg WN, Cohen LJ, Whitman WG, 1907. Ammonia in milk and its development during proteolysis under the influence of strong antiseptics. J Biol Chem, 3: 171-175.

Shipe WF, Ledford RA, Peterson RD, Scanlan RA, Geerken HF, Dougherty RW, Morgan ME, 1962. Physiological mechanisms involved in transmitting flavors and odors to milk. II. Transmission of some flavor components of silage. J Dairy Sci, 45: 477-480.

Silanikove N, Leitner G, Merin U, Prosser CG, 2010. Recent advances in exploiting goat's milk: quality, safety and production aspects. Small 
Rumin Res, 89: 110-124.

Skjevdal T, 1979. Flavor of goat's milk: A review of studies on the sources of its variations. Livest Prod Sci, 6: 397-405.

van Duinkerken G, Smits MCJ, Andre G, Sebek LBJ, Dijkstra J, 2011. Milk urea concentration as an indicator of ammonia emission from dairy cow barn under restricted grazing. J Dairy Sci, 94:321-335.
Citation: Hayashi Y, Ueno N, 2018. Comparative evaluation of odorous compound absorption between goat milk and cow milk. Net J Agric Sci, 6(1): 6-10. 